\title{
Predictors of knowledge transfer between expatriates and host country nationals Shared vision as mediator
}

Predictors of knowledge transfer

\author{
Nurul Afiqah Zulkifly, Maimunah Ismail and Siti Raba'ah Hamzah \\ Department of Professional Development and Continuing Education, \\ Universiti Putra Malaysia, Serdang, Malaysia
}

\begin{abstract}
Purpose - The purpose of this paper is to investigate the influences of cultural intelligence, feedback-seeking behavior and shared vision as a mediator on bi-directional knowledge transfer involving expatriates and host country nationals (HCNs).

Design/methodology/approach - This paper integrates the signaling theory, the social capital theory and the anxiety and uncertainty theory in investigating the relationships between predictors and knowledge transfer in a bi-directional manner. The participants of the study were 125 expatriate-HCN pairs of MNCs and local organizations in the areas of Klang Valley, Malaysia.

Findings - Shared vision was found to significantly mediate the influences of cultural intelligence and feedback-seeking behavior on knowledge transfer as perceived by the respective respondents.

Originality/value - Co-existence between expatriates and HCNs leads to many organizational outcomes including knowledge transfer. This paper additionally provides theoretical and practical implications to human resource practices.
\end{abstract}

Keywords Shared vision, Expatriate, Cultural intelligence, Bi-directional knowledge transfer,

Feedback-seeking behaviour, Host country national

Paper type Research paper

\section{Introduction}

Literature indicates that knowledge transfer is a phenomenon contributing to organizational outcomes that involve both internal and external resources in developed and developing countries (Cassiman and Veugelers, 2006). Among the internal resources are individual and social factors of employees. It is commonly accepted that organizations vary widely in their capability to develop and understand these internal resources (Ismail et al., 2018). Thus, the focus of this research, i.e. the determinants of knowledge transfer (individual and social capital factors) is relevant to Cohen and Levinthal's (1989) idea of firms' absorptive capacity that should be capitalized on (Comeig $e t$ al., 2018) in addition to the benefit obtained from external resources.

Knowledge transfer constitutes processes at individual, departmental and organizational level (Argote, 2012; Nery-Kjerfve and McLean, 2012). However, authors have been specifically silent on the role of expatriate- $\mathrm{HCN}$ relationships in knowledge transfer with the presence of shared vision as a mediator, particularly in the context of a developing country. Additionally, past studies focused on the unidirectional form of knowledge transfer from expatriates to HCNs, failing to unravel the bi-directional form of knowledge transfer

(C) Nurul Afiqah Zulkifly, Maimunah Ismail and Siti Raba'ah Hamzah. Published in European Journal of Management and Business Economics. Published by Emerald Publishing Limited. This article is published under the Creative Commons Attribution (CC BY 4.0) licence. Anyone may reproduce, distribute, translate and create derivative works of this article (for both commercial \& non-commercial purposes), subject to full attribution to the original publication and authors. The full terms of this licence may be seen at http://creativecommons.org/licences/by/4.0/legalcode

Received 15 April 2019 Revised 23 August 2019 Accepted 25 September 2019

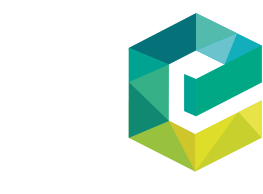

European Journal of Management and Business Economics Vol. 29 No. 2, 2020 pp. 199-215 Emerald Publishing Limited e-ISSN: 2444-8494 p-ISSN: $2444-845$ DOI 10.1108/EJMBE-04-2019-0067 
EJMBE

29,2

200

from expatriates to locals and vice versa (Chang et al., 2012). Nonetheless, the available literatures have been focusing on the general mechanisms of knowledge transfer and expatriations (Minbaeva and Michailova, 2004; Smale and Suutari, 2011) with less concern on the process occurred within an organization through the involvement of both groups of professionals. Internationally, a study by Hsu (2012) was conducted to empirically prove the bi-directional form of knowledge transfer between expatriates and HCNs involving different theoretical and methodological scope with samples from wider geographical coverage (USA, Taiwan, China, Vietnam, South Korea, Thailand, Malaysia and India). To our knowledge, there has been no study focusing on specific bi-directional knowledge transfer between expatriates and HCNs using internal resources, which are also known as individual and social capital variables based on Malaysia context.

The research questions of this study are:

$R Q 1$. Do individual factors of cultural intelligence and feedback-seeking behavior significantly influence knowledge transfer between expatriates and HCNs, bi-directionally?

$R Q 2$. Does shared vision mediate the relationship between individual factors and knowledge transfer between expatriates and HCNs, bi-directionally?

Therefore, the objectives of this research are: to examine the influence of cultural intelligence and feedback-seeking behavior on knowledge transfer between expatriates and HCNs, bi-directionally; and to identify the mediating role of shared vision in the relationships of cultural intelligence and feedback-seeking behavior on knowledge transfer between expatriates and HCNs, bi-directionally. Shared vision is chosen because it is a mechanism that embodies the collective goals and aspirations of members in an organization to integrate or combine resources (Tsai and Ghoshal, 1998). Furthermore, shared vision is a reflection of cognitive dimension of social capital that is unifying in nature (Expósito-Langa et al., 2010).

Vision refers to a clear anticipation of future outcome. Shared vision is a connecting mechanism that helps different groups of employees (such as expatriates and HCNs) to unite and work together harmoniously. Upadhyayula and Kumar (2004) assert that shared vision facilitates the role of individual's internal resources and social capital factors, and shared vision could mediate the influence of internal resources on knowledge transfer. Shared vision is a cognitive dimension of social capital other than its strength (relational or ties). It is also related to collective objective and aspiration. Under these relational conditions members of the organization thus have more opportunities for a freedom to exchange ideas and resources.

The notion of shared vision was used widely in the field of organizational development. Shared vision is related to the traditional concept of goal-oriented implementation and consensus building in strategy and leadership literatures (Expósito-Langa et al., 2010). Other literature on organizational learning also emphasized the concept of consensus building, and calls for better understanding of shared vision as a transformational mechanism of a learning organization (Senge, 2006). Wang and Rafiq (2009) highlight that shared vision is one of the predictors of organizational outcome that emphasizes bottom-up approach of management. This implies shared vision is an important construct used in managing human resources.

Thus, this paper empirically studies expatriates and HCNs in MNCs and organizations in the most vibrant Malaysian industrial areas, Klang Valley, and its new expansion area of Greater Kuala Lumpur. MNCs and organizations choose Klang Valley and Greater Kuala Lumpur as their Asia-base as these areas are powerful magnet attracting investors for investment opportunities in the country (Deng, 2012). Klang Valley is ranked as a mega world city in 2018 due to its economic, financial and cultural achievement, other than having a high Human Development Index in terms of life expectancy, education and income per 
capita (Department of Statistics Malaysia, 2018). In Malaysia, there is a total of $921 \mathrm{MNCs}$ and organizations comprising of both international based and local based (www. malaysiaplc.com/directory/listed-companies/). Following that, a sample of $30 \mathrm{MNCs}$ and organizations were randomly selected out of the $921 \mathrm{MNCs}$ population and it was found that 28 of them (93.33 percent) resides in the Klang Valley, Malaysia. This implies the significance of Klang Valley as the location of this research.

The number of expatriates in Malaysia in 2016 (Department of Statistics Malaysia, 2018) was 133,108, an increase from 90,000 in 2014 recorded by the Department of Immigrant, Malaysia (Pinto, 2014). Their presence in the country (with a population of $32.4 \mathrm{~min} 2018$ is), helps to improve the total number of skilled human resources from whom the local employees may gain benefits through mutual knowledge transfer. This is one of the country's strategies to call for stronger involvement of private sector in the economic transformation initiatives as stipulated in the New Economic Model of Malaysia (NEAC, 2010) toward achieving a high-income status nation by 2020 and beyond. In 2018, Kuala Lumpur has been crowned sixth best city in the world for expatriates, according to Expat City Ranking 2018 (New Straits Times, 2018).

Ismail et al.'s (2016) research supports the significant role played by shared vision as a mediator between the determinants of knowledge transfer, bi-directionally. Thus, this study is imperative to MNCs and organizations where there are co-existence of expatriates and HCNs, which adds to workplace diversity (Ismail and Arokiasamy, 2008). The next section presents the theoretical framework of this study, followed by research hypotheses, methodological procedures, conclusions as well as theoretical and practical implications of the study.

\section{Theoretical justification and literature review}

Three theories were used to support the research framework of this study. First is the signaling theory (Spence, 2002; Connelly et al., 2011) that investigates communication between individuals or parties. Primarily, signaling theory is concerned with the reduction of information asymmetry between the provider and receiver of knowledge. Information asymmetry refers to different levels of knowledge accessed and possessed by two parties. Typically, one party, the sender, must choose whether and how to communicate (or signal) that information, and the other party, the receiver, must choose how to interpret the signal. Scholars in the field of management have applied signaling theory to enlighten the influence of information asymmetry including knowledge transfer. In order to have an equilibrium between the two parties, knowledge needs to flow or transfer from one party to another. In the context of this study, this theory highlights the bi-directional transfer of knowledge from expatriate to $\mathrm{HCN}$ and vice versa.

The anxiety and uncertainty management theory (Gudykunst, 1998) is the second theory, which deliberates the personal qualities such as cultural intelligence and feedbackseeking behavior of individuals in organizations. Anxiety occurs when a person faces problem while he/she interacts with others of dissimilar socio-cultural backgrounds (Yoshitake, 2002), and it is emotionally correspondent with uncertainty. Cognitively, uncertainty is a dimension that effects the way one person understands the other, while anxiety tends to decrease as people familiarize themselves with each other. In cross-cultural setting, anxiety and uncertainty are critical determinants influencing the nature of intergroup communication. Absence of communication from the inability to culturally compromise due to personal qualities might hinder knowledge transfer (Oddou et al., 2009). Thus, this theory supports the investigation of the relationship between cultural intelligence as well as feedback-seeking behavior and knowledge transfer.

The social capital theory (Nahapiet and Ghoshal, 1998; Lin, 1999), on the other hand, describes resources available and derived from the network of relationships possessed by members in a social entity. These social resources include social ties, trusting relations and

Predictors of knowledge transfer 
EJMBE

29,2

202

value system, that promote interactions and bi-directional communication between expatriates and HCNs (Song et al., 2003; Ismail, 2015). Bi-directional relationship is also emphasized by previous scholars as one of the predictors of successful knowledge transfer (Van Wijk et al., 2008; Ismail et al., 2019), which includes shared vision. Song et al.'s (2003) inter-firm knowledge transfer study in the USA highlights the importance of two-way knowledge transfer i.e. from the hired employees to the hiring firm and vice versa. From these arguments, it is justifiable that the social capital theory and the other two theories support the mediating role of shared vision in the relationship between cultural intelligence and feedback-seeking behavior within the two-way knowledge transfer process involving expatriates and HCNs.

\subsection{Hypothesis development: determinants of knowledge transfer}

2.1.1 Cultural intelligence and knowledge transfer. Cultural intelligence is the intercultural competence that requires one to be socially sensitive within a cross-cultural work environment setting (Hsu, 2012; Nery-Kjerfve and McLean, 2012). In the context of this study, cultural intelligence in knowledge transfer process is regarded as the ability of expatriates as both learners (Feitosa et al., 2014) and players (Tsang, 2001; Kodwani, 2012) to adapt with different cultural settings. In other words, high level of cultural intelligence allows expatriates or HCNs to be more content when interacting with people from different cultures, and to effortlessly share organizational goal together. This implies that expatriates must be willing to cope with cultural challenges in their social interactions with HCNs and vice versa. A study in Taiwan indicates that meaningful interactions between expatriates and HCNs are expected from high level of cultural intelligence and therefore, should facilitate bi-directional knowledge transfer process between them (Chang et al., 2012). Thus, we hypothesize that:

$H 1 a-b$. Cultural intelligence influences knowledge transfer between expatriates and HCNs in bi-directional form.

2.1.2 Feedback-seeking behavior and knowledge transfer. In a study among medical doctors, feedback-seeking behavior is referred as proactive personal behavior that helps self-growth of professionals in adapting, learning and performing (Crommelinck and Anseel, 2013). This can also be applied in the context of expatriates, repatriates and top management personnel in international firms to promote cross-border assignments (Crowne, 2009). Krasman's (2010) in-depth investigation regarding feedback-seeking behavior among part-time university business students who work full-time in the USA has found that the students portray their feedback-seeking behavior as a partial attribute of his or her personality, which then influences knowledge transfer between two or more people. Feedback-seeking behavior empowers individuals to assess themselves and learn through mistakes as evaluated by others. Feedback-seeking behavior is also associated with opportunity seeking as one of the predictors of knowledge received by subsidiary and subsequently its performance (Chang et al., 2012).

A theoretical model has associated feedback-seeking behavior to three psychological variables: task information; self-efficacy; and feedback utilization (VandeWalle's, 2004). In this paper, task information requires feedback from both expatriates and HCNs to one another in order for them to correct work-related errors. Self-efficacy nonetheless, is the ability of oneself to execute a course of action that is fundamentally required in producing certain desired outcome such as knowledge transfer. Feedback utilization is the extent to which expatriates and HCNs in organizations are able to make specific changes according to the feedback they received from one another. A supervisor-employee dyads study in the USA (De Stobbeleir et al., 2011) and a reverse knowledge flow study in MNCs in Sweden 
(Kumar, 2013) explain that employees who perform skillfully at work are those who constantly sought after feedbacks. Thus, we hypothesize that:

$H 2 a-b$. Feedback-seeking behavior influences knowledge transfer between expatriates and HCNs in bi-directional form.

2.1.3 Shared vision and knowledge transfer. Inkpen and Tsang (2005) referred to shared vision, a vital cognitive element of social capital, as the extent to which different people share one common, long-term goals and visions. Social exchanges between expatriates and HCNs are specifically crucial in transferring tacit knowledge as tacit knowledge is intangible in nature. A study conducted among Bank Loan Managers in Chicago, USA, revealed that learning through knowledge transfer is also located in the relationships among individuals (Uzzi and Lancaster, 2003), which is through shared vision. Bonache and Zárraga-Oberty's (2008) study show the role of collaborative interpersonal relationships between international and local employees in achieving fruitful knowledge transfer in MNCs and organizations. Shared vision promotes mutual understanding and acts as a crucial bonding mechanism that supports different parties to incorporate knowledge transfer as expatriates and HCNs cover a diverse cultural background (Hsu, 2012). This implies the significance of bi-directional flow of knowledge transfer between expatriates and HCNs. Thus, it is hypothesized that:

$H 3 a-b$. Shared vision influences knowledge transfer between expatriates and HCNs in bi-directional form.

2.1.4 Shared vision as a mediator. Lin's (2017) social capital theory asserts that a mediator is essential in any communication process involving senders and receivers. The anxiety and uncertainty management theory postulates that cultural intelligence and feedback-seeking behavior help to reduce distant relationship among expatriates and HCNs. In order to achieve common sets of goals, collective collaboration is needed. Ado et al's (2016) study involving 12 Africa-China joint ventures indicates that collaboration between Africans and their local co-workers hinders due to the lack of cultural intelligence. Feedback-seeking behavior is considered as a self-regulatory constructive behavior (Krasman, 2010) because individuals adjust their behavior based on feedback that they gained from others in order to become more acceptable to others and consequently shared vision is achieved (Ashford et al., 2003). Feedback-seeking behavior facilitates the performer to achieve better clarification pertaining to his/her vision, in terms of what he/she could do in an organization because individuals normally strive toward excellence in work when goal and what to do are clear (Robert et al., 2005).

Scholars emphasize shared vision as a psychological determinant of social bonds, which entails familiarity and confidence in a relational exchange (Roueche et al., 2014). An intra and inter-firm study in western MNCs' subsidiaries in China revealed that shared vision is a mandatory requirement in the manifestation of exchange process $(\mathrm{Li}, 2005)$. Shared vision among diverse cultures promotes mutual understanding, which influences knowledge transfer. Absorptive capacity in knowledge acquisition and transfer among high-tech firms located in the UK was found to expand due to shared vision established in expatriate-HCN pairs (Yli-Renko et al., 2001). It was also found that shared vision was significant in knowledge transfer involving highly culturally-diverse interaction (Bresman et al., 1999). Thus, it is hypothesized that:

$H 4 a-d$. Shared vision mediates the relationship between cultural intelligence as well as feedback-seeking behavior and knowledge transfer between expatriates and HCNs in bi-directional form.

2.1.5 Bi-directional analysis of knowledge transfer. An expatriate and $\mathrm{HCN}$ pair maintains a sociologically significant relationship in a workplace. The expectation on mutual gain and

Predictors of knowledge transfer 
EJMBE 29,2

\section{4}

Figure 1.

Research framework of expatriate-HCN knowledge transfer (from expatriate's perspective) reciprocity in the responses of the members caused an interdependency between expatriates and their HCNs counterparts (Kashy and Kenny, 2000). Realizing that past studies have been disregarding the vital contributions made by $\mathrm{HCNs}$ in order to advocate an effective bi-directional knowledge transfer process within organizations (e.g. Smale and Suutari, 2011; Minbaeva and Michailova, 2004), albeit HCNs are indeed as important as expatriates because they complement each other in the bi-directional knowledge flow (Caligiuri and Cascio, 1998). In this study, it is proposed that the reciprocity between the pairing members leads to the process of bi-directional knowledge transfer. The relevant social factor is mutual shared vision at workplace. Based on the above literature arguments, the framework of this study is shown in Figures 1 and 2 from the perspectives of expatriates and HCNs, respectively.

\section{Methodology}

\subsection{Subject of research}

The research subjects of this study are expatriate-HCN pairs. We identified expatriates by various means as follows: organizations with expatriate employees were traced through Companies Commission of Malaysia (CCM) database; the HR division of each organization was contacted through emails, followed by phone calls inviting them to participate in the study; and a set of online questionnaire was emailed and linked with the Google Form. In addition, the researchers met several international consultants, to get assistance from them to introduce the researchers to expatriates in their network. Each identified expatriate was then required to recommend one $\mathrm{HCN}$ that s/he works best with, in an MNC or company to establish an expatriate-HCN pair. These expatriate-HCN pairs whom the researchers contacted were employees in MNCs and private companies in the areas of Klang Valley and its vicinity of Greater Kuala Lumpur. The total respondents obtained with complete questionnaires were 125 expatriate-HCN pairs involving $36 \mathrm{MNCs}$ categorized under 10 different industries, including airlines, engineering, oil and gas, education, consultancy, automotive, insurance, online retailing, retailing and hospitality industries. As a whole, the respondents were obtained using simple random sampling technique, in which each expatriate in the population has equal chance of being selected as study sample. Mohd Tahir

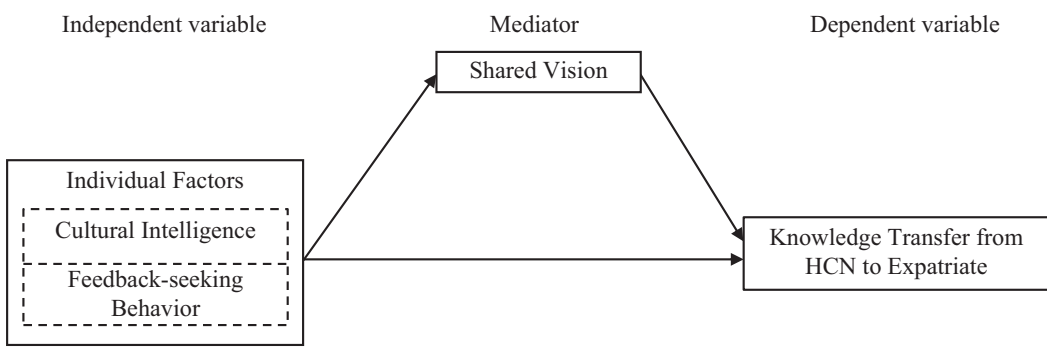

Independent variable

Mediator

Dependent variable

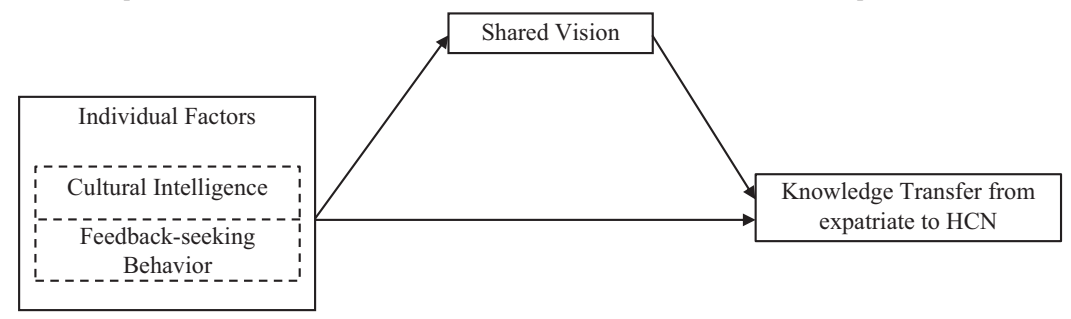

Figure 2 .

A research framework of expatriate-HCN knowledge transfer (from HCN's perspective) 
and Ismail's (2007) research findings on work adaptation of expatriates in the Klang Valley were appropriately used for generalization. It is therefore believed that the sample used in this study justifies the representativeness of expatriate-HCN pairs in Malaysia.
Predictors of knowledge transfer

\subsection{Study instrument and data collection}

We used validated survey questionnaire to gauge knowledge transfer, cultural intelligence, feedback-seeking behavior and shared vision. Knowledge transfer construct was measured using the instrument by Dhanaraj et al. (2004) consisting a six-item questions with a seven-point Likert-type scale. This instrument requires the expatriates and $\mathrm{HCN}$ s to evaluate the extent to which they have learnt tacit knowledge such as "new marketing skill," knowledge about foreign cultures and tastes, as well as "managerial techniques" from their respective counterparts. The expatriates and HCNs are also required to evaluate the extent to which they have learnt explicit knowledge such as "written knowledge about firm's technology," "procedural or technical information," and "written knowledge about management techniques" from their expatriate/HCN colleagues.

Cultural intelligence was measured using instrument from Ang and Van Dyne (2015), which consists of a nine-item questionnaire with a five-point Likert-type scale. Expatriates and HCNs are required to rate the extent to which they agree with statements such as "I know the values and religious beliefs of other cultures.” Feedback-seeking behavior is measured using the instrument from Ashford (1986). The measurement consists of a seven-item questionnaire with a five-point Likert-type scale where expatriates and HCNs are required to rate the extent to which they agree with statements in the instrument such as "I would like to get feedback on what behaviors will help me advance within the company." Shared vision was measured using the instrument developed by Gutiérrez et al. (2009). It consists of a six-item questionnaire with a five-point Likert-type scale to measure the extent to which respondents have engaged in shared vision. For this item, expatriates and HCNs are required to rate the extent to which they agree with statements in the instrument such as "My HCN/expatriate colleague and I share a clear vision guiding the strategic goals and missions of the organization." Cronbach's $\alpha$ values of the constructs in the instrument ranged from 0.78 to 0.92 .

\subsection{Data analysis}

A research is considered exploratory when researcher believes that certain research is worth discovering, even though there is little or no scientific knowledge about the group, process, activity or situation to be examined (Stebbins, 2001). Confirmatory research approach in contrast, seeks to test and confirm hypotheses based on previous research on the subject matter, which in this case is knowledge transfer, using existing theories (Jaeger and Halliday, 1998). In the context of this paper, the hypotheses were derived by integrating three existing theories in investigating the bi-directional approach of knowledge transfer. Thus, it is confirmatory in nature. Data were analyzed using IBM SPSS 24 to produce descriptive and inferential results. The descriptive analysis reports the mean, standard deviation, percentage and range for the demographic and professional profiles of the respondents. The inferential statistics were used to test the hypotheses of the study. They include Pearson's product-moment correlation prior to multiple linear regression analyses.

The mediation role of shared vision on the relationship between the antecedents and knowledge transfer was analyzed using PROCESS IBM SPSS 24 by Hayes (2013) as suggested by Preacher and Hayes $(2004,2008)$. This method examines the total direct effect and the indirect effect of specified shared vision as mediator in the relationship between the independent variables and knowledge transfer, controlling for the other antecedents. It is considered superior relative to others such as that by Baron-Kenny (1986) in mediation testing (Molina et al., 2013). It was previously used by Molina et al. (2013) in their cancer research, Lazuras et al. (2013) in their cyberbullying among adolescence research, 
EJMBE

29,2

\section{6}

Manzi et al. (2018) in their cross-cultural and cross-generational study, Jawahar and Schreurs (2018) in their supervisor-subordinate study, Peraza et al. (2019) in their distress tolerance and cessation-related cannabis research, as well as Caniëls' (2019) proactivity and supervisor support in creative process engagement research. Hayes (2013) verified that PROCESS OLS regression coefficients and standard errors were found to be extremely similar as compared to other SEM programs.

\subsection{Profile of respondents}

The sample of expatriate consists of 75.20 male and 24.80 percent female respondents. They represent 26 nationalities in which Indian expatriates make up the largest group (18.40 percent), followed by Japanese and Indonesian (16.00 percent, respectively), and British (12.00 percent), as well as American (4.80 percent). German, Filipino and Singaporean each makes up to 4.00 percent, while Italian and Thailand constitute 2.40 percent. The rest are Palestinian, Irish and Australian each makes up to 1.60 percent and other nationalities include Canadian, Chinese, Danish, Sri Lankan, French, Iranian, Nepalese, Nigerian, Russian, Serbian, Spanish, Turkish and Uzbek. Most of the expatriate respondents are in the age range from 35.1 to 45 years ( 36.00 percent, mean $=41.42, \mathrm{SD}=9.31$ ). While for the HCNs, they consist of 64.40 percent male and majority (44.80 percent) are 35 years old and below (mean $=37.65, \mathrm{SD}=8.39$ ). The demographic and nationality profiles of the respondents are shown in Tables I and II, respectively.

A total of 29.60 percent of the expatriate-HCN pairs work in the engineering sector, followed by 17.60 percent in consulting services, 16.80 percent in airlines, 15.20 percent oil and gas, 8.80 percent education, 4.80 percent automotive, insurance and online retailing (2.40 percent each), 1.60 percent in retailing and only 0.80 percent in hospitality industry. These industries are important contributors toward Malaysia's economic growth by 2020 and beyond (Tan and Yap, 2015).

The expatriates and HCNs have been working for their companies for an average of 3.60 years $(\mathrm{SD}=2.59)$ and 7.11 years $(\mathrm{SD}=5.34)$, respectively. Expatriation is an essential approach in facilitating cross-border knowledge transfer, which requires them to live in foreign business areas for several years for them to collect and share the necessary experiences (Webb, 1996). Therefore, expatriates are expected to use the experiences they gained from abroad in their organizations upon their return. This is one of the reasons for expatriates do not work at a certain foreign country for a long period of time.

\section{Results and discussion}

Table III shows paired sample $t$-test results. The level of cultural intelligence shows a significant difference between expatriates and HCNs. The mean of expatriates (4.103) is

\begin{tabular}{|c|c|c|c|c|c|c|}
\hline Variables & Freq. & $\begin{array}{l}\text { Expatriate } \\
\text { Percent }(\%)\end{array}$ & Mean (SD) & Freq. & $\begin{array}{r}\mathrm{HCN} \\
\text { Percent }(\%)\end{array}$ & Mean (SD) \\
\hline \multicolumn{7}{|l|}{ Gender } \\
\hline Male & 94 & 75.20 & \multirow{8}{*}{41.42 (9.31) } & 78 & 62.40 & \multirow{8}{*}{$37.65(8.39)$} \\
\hline Female & 31 & 24.80 & & 47 & 37.60 & \\
\hline Age (year) & & & & & & \\
\hline $25.0-35.0$ & 40 & 32.00 & & 56 & 44.80 & \\
\hline $35.1-45.0$ & 45 & 36.00 & & 44 & 35.20 & \\
\hline $45.1-55.0$ & 34 & 27.20 & & 23 & 18.40 & \\
\hline $55.1-65.0$ & 3 & 2.40 & & 2 & 1.60 & \\
\hline 65.1 and above & 3 & 2.40 & & 0 & 0.00 & \\
\hline Note: $n=125 \mathrm{p}$ & & & & & & \\
\hline
\end{tabular}

Table I.

Demographic profile of respondents

Note: $n=125$ pairs 


\begin{tabular}{|c|c|c|c|c|c|}
\hline \multirow[b]{2}{*}{ Variables } & & & \multicolumn{2}{|c|}{ Expatriate } & \multirow{2}{*}{$\begin{array}{r}\text { Predictors of } \\
\text { knowledge }\end{array}$} \\
\hline & & & Freq. $(f)$ & Percent $(\%)$ & \\
\hline \multicolumn{3}{|l|}{ Countries in Asia } & 86 & 68.80 & \\
\hline \multicolumn{3}{|l|}{ India } & 23 & 18.40 & \\
\hline \multicolumn{3}{|l|}{ Japan } & 20 & 16.00 & \\
\hline \multicolumn{3}{|l|}{ Indonesia } & 20 & 16.00 & \\
\hline \multirow{2}{*}{\multicolumn{3}{|c|}{ The Philippines }} & 5 & 4.00 & 207 \\
\hline & & & 5 & 4.00 & \\
\hline \multicolumn{3}{|l|}{ Thailand } & 3 & 2.40 & \\
\hline \multicolumn{3}{|l|}{ Palestine } & 2 & 1.60 & \\
\hline \multicolumn{3}{|c|}{ Others (China, Iran, Nepal, Nigeria, Sri Lanka, Turkey, Uzbekistan) } & 8 & 6.40 & \\
\hline \multirow{2}{*}{\multicolumn{3}{|c|}{ Countries outside Asia }} & 39 & 31.20 & \\
\hline & $\begin{array}{l}\text { UK } \\
\text { USA }\end{array}$ & & 15 & 12.00 & \\
\hline \multicolumn{3}{|l|}{ USA } & 6 & 4.80 & \\
\hline \multicolumn{3}{|l|}{ Germany } & 5 & 4.00 & \\
\hline \multicolumn{3}{|l|}{ Italy } & 3 & 2.40 & \\
\hline \multicolumn{3}{|l|}{ Ireland } & 2 & 1.60 & \\
\hline \multicolumn{3}{|l|}{ Australia } & 2 & 1.60 & Table II. \\
\hline \multirow{2}{*}{\multicolumn{3}{|c|}{ Others (Canada, Denmark, France, Russia, Serbia, Spain) }} & 6 & 4.80 & Country of origin of \\
\hline \multicolumn{2}{|l|}{ Note: $n=125$ pairs } & & & & expatriates \\
\hline Variables & Mean & SD & $t$ & $p$ & \\
\hline \multicolumn{3}{|l|}{ Knowledge Transfer } & 1.582 & 0.116 & \\
\hline \multicolumn{3}{|l|}{ Expatriate } & & & \\
\hline $\mathrm{HCN}$ & 4.282 & 1.235 & & & \\
\hline & 0.306 & 0.760 & \\
\hline \multicolumn{3}{|l|}{$\begin{array}{l}\text { Shared vision } \\
\text { Expatriate }\end{array}$} & & & \\
\hline $\mathrm{HCN}$ & 3.960 & 0.631 & & & \\
\hline \multicolumn{3}{|l|}{ Cultural intelligence (CQ) } & 3.357 & 0.001 & \\
\hline Expatriate & 4.103 & 0.566 & & & \\
\hline & 3.883 & 0.535 & & & \\
\hline \multirow{3}{*}{$\begin{array}{l}\text { Feedback-seeking behavior (FSB) } \\
\text { Expatriate } \\
\text { HCN } \\
\text { Notes: } n=125 \text { Pairs. } p<0.05\end{array}$} & & & 0.118 & 0.907 & Table III. \\
\hline & 3.880 & 0.788 & & & Paired sample $t$-test \\
\hline & 3.869 & 0.691 & & & for difference in the \\
\hline \multicolumn{3}{|l|}{ Notes: $n=125$ Pairs. $p<0.05$} & & & levels of variables \\
\hline
\end{tabular}

higher than that of HCNs (3.883). This implies that expatriates are more sensitive and prepared about intercultural competence in their task of transferring knowledge with the locals. This difference may suggest variation in the potential influence of the predictors of knowledge transfer in this study.

Pearson product-moment correlation analysis results from expatriate sample (Table IV) indicate the highest value is shared vision $(r=0.473, p=0.000)$, followed by feedback-seeking behavior $(r=0.324, p=0.000)$ and cultural intelligence $(r=0.299, p=0.001)$. Similarly, the highest value for HCN sample (Table V) is shared vision $(r=0.388, p=0.000)$, followed by feedback-seeking behavior $(r=0.300, p=0.001)$ and cultural intelligence $(r=0.255, p=0.004)$. The results validate that both expatriate and $\mathrm{HCN}$ respondents experience high level of individual factors i.e. cultural intelligence and feedback-seeking behavior and these variables have predictive potential to knowledge transfer.

Only shared vision $(\beta=0.408, p=0.000)$ significantly influences knowledge transfer from HCNs, as perceived by expatriates (Table VI). Cultural intelligence and feedback-seeking 
EJMBE 29,2

\section{8}

Table IV.

Matrix of correlation of variables (expatriate sample)

behavior however, do not significantly influence knowledge transfer from $\mathrm{HCNs}$, as perceived by expatriates. Therefore, $H 3 a$ is supported in this study while $H 1 a$ and $H 2 a$ are not supported. Similarly, only shared vision $(\beta=0.308, p=0.001)$ significantly influences knowledge transfer from expatriates as perceived by HCNs. Cultural intelligence and feedback-seeking behavior were not found to have significant influence on knowledge transfer. Thus, $H 3 b$ is supported while $H 1 b$ and $H 2 b$ are not supported. The respective adjusted $R^{2}$ values of 0.222 and 0.159 for expatriates and HCNs imply that shared vision explains 22.20 and 15.90 percent of the variance in knowledge transfer as perceived by expatriates and HCNs, respectively. However, when the regression analysis was re-run, the new adjusted $R^{2}=0.218$ and $R^{2}=0.144$ were obtained for the respective expatriates and HCNs (Table VII). This shows that the direct influence of shared vision on knowledge transfer is with the explanatory power of 21.80 and 14.40 percent for the respective expatriate and HCN samples.

The PROCESS procedure (Hayes, 2013) was used for the bootstrapping analysis. PROCESS can construct bias-corrected percentile and Monte Carlo Confidence Interval (CI)

\begin{tabular}{lcccc}
\hline & $\begin{array}{c}\text { Knowledge } \\
\text { transfer } \\
r(p)\end{array}$ & $\begin{array}{c}\text { Shared } \\
\text { vision } \\
r(p)\end{array}$ & $\begin{array}{c}\text { Cultural } \\
\text { intelligence } \\
r(p)\end{array}$ & $\begin{array}{c}\text { Feedback-seeking } \\
\text { behavior } \\
r(p)\end{array}$ \\
\hline $\begin{array}{l}\text { Knowledge transfer } \\
\text { Shared vision }\end{array}$ & 0.888 & & & \\
Cultural intelligence & $0.473(0.000)$ & 0.921 & & \\
Feedback-seeking behavior & $0.299(0.001)$ & $0.382(0.000)$ & 0.828 & 0.932 \\
Note: Diagonal figures are the reliability values of the variables & & \\
\hline
\end{tabular}

\begin{tabular}{|c|c|c|c|c|}
\hline & $\begin{array}{c}\text { Knowledge } \\
\text { transfer } \\
r(p)\end{array}$ & $\begin{array}{l}\text { Shared } \\
\text { vision } \\
r(p)\end{array}$ & $\begin{array}{c}\text { Cultural } \\
\text { intelligence } \\
r(p)\end{array}$ & $\begin{array}{c}\text { Feedback-seeking } \\
\text { behavior } \\
r(p)\end{array}$ \\
\hline Knowledge transfer & 0.863 & & & \\
\hline Shared vision & $0.388(0.000)$ & 0.915 & & \\
\hline Cultural intelligence & $0.255(0.004)$ & $0.414(0.000)$ & 0.814 & \\
\hline Feedback-seeking behavior & $0.300(0.001)$ & $0.379(0.000)$ & $0.502(0.000)$ & 0.945 \\
\hline
\end{tabular}

Table V. Matrix of correlation of variables (HCN Sample)

\begin{tabular}{lccccc}
\hline Variables & $B$ & $S E(B)$ & $\beta$ & $t$ & $p$ \\
\hline Expatriate & & & & & \\
Constant & 0.058 & 0.854 & & 0.068 & 0.946 \\
Shared vision & 0.747 & 0.182 & 0.408 & 4.097 & 0.000 \\
Cultural intelligence & 0.321 & 0.218 & 0.132 & 1.470 & 0.144 \\
Feedback-seeking behavior & 0.045 & 0.180 & 0.026 & 0.250 & 0.803 \\
HCN & & & & & \\
Constant & 0.364 & 0.844 & & 0.432 & 0.667 \\
Shared vision & 0.604 & 0.181 & 0.308 & 3.326 & 0.001 \\
Cultural intelligence & 0.109 & 0.229 & 0.047 & 0.476 & 0.635 \\
Feedback-seeking behavior & 0.285 & 0.174 & 0.160 & 1.637 & 0.104
\end{tabular}

Table VI.

Results of multiple linear regression
Notes: Expatriate $\rightarrow p<0.05 ; F=12.781$; Sig. $F=0.000 ; R=0.491 ; R^{2}=0.241 ;$ Adjusted $R^{2}=0.222$. $\mathrm{HCN} \rightarrow p<0.05 ; F=8.837$; Sig. $F=0.000 ; R=0.424 ; R^{2}=0.180$; Adjusted $R^{2}=0.159$ 
for indirect effects. Table VIII presents results of mediating effect of shared vision on the relationships between cultural intelligence as well as feedback-seeking behavior and knowledge transfer between expatriates and HCNs bi-directionally. The determination of mediation effect of shared vision is based on "zero" ( 0 ) value location in confidence interval (CI) (Hayes, 2009, p. 412) in which if CI does not contain "zero" (0) value, it means the indirect or mediation effect is statistically significant.

Table VIII further indicates that the bias-corrected $95 \%$ percentile of CI ( $\beta=0.392$, $\mathrm{CI}=0.205,0.659, p<0.05)$ does not include zero value. These findings revealed that the indirect effect of cultural intelligence on knowledge transfer through the mediator (shared vision) as perceived by expatriates is statistically significant. As for feedback-seeking behavior, the bias-corrected $95 \%$ percentile of $\mathrm{CI}(\beta=0.447, \mathrm{CI}=0.242,0.729, p<0.05)$ does not include zero value. Similarly, shared vision mediates significantly the relationship between feedback-seeking behavior and knowledge transfer, as perceived by expatriates. Therefore, $H 4 a$ and $H 4 c$ are supported.

Results also show that the bias-corrected $95 \%$ percentile of $\mathrm{CI}(\beta=0.326, \mathrm{CI}=0.121$, $0.594, p<0.05)$ does not include zero value. These findings show that shared vision mediates the influence of cultural intelligence on knowledge transfer as perceived by HCNs. Likewise, the bias-corrected $95 \%$ percentile of $\mathrm{CI}(\beta=0.217, \mathrm{CI}=0.079,0.438, p<0.05)$ does not include zero value, which indicates the significant mediation of shared vision on the influence of feedback-seeking behavior on knowledge transfer, as perceived by HCNs. Thus, $H 4 b$ and $H 4 d$ are supported as well.

Based on the findings of the study, the results of the overall testing of hypotheses are summarized as illustrated in Table IX.

This study shows the importance of shared vision in the knowledge transfer process involving expatriates and HCN employees. This is an advantage to the organizations as it

\begin{tabular}{lccccc}
\hline Variables & $B$ & $S E(B)$ & $\beta$ & $t$ & $p$ \\
\hline $\begin{array}{l}\text { Expatriate } \\
\text { Constant }\end{array}$ & 1.078 & 0.583 & & & \\
Shared vision & 0.867 & 0.145 & 0.473 & 5.948 & 0.067 \\
HCN & & & & 2.355 & 0.000 \\
Constant & 1.453 & 0.617 & & 4.622 & 0.020 \\
Shared vision & 0.715 & 0.155 & 0.373 & 000
\end{tabular}

Notes: Expatriate $\rightarrow p<0.05 ; F=35.497$; Sig. $F=0.000 ; R=0.473 ; R^{2}=0.224 ;$ Adjusted $R^{2}=0.218$. $\mathrm{HCN} \rightarrow p<0.05 ; F=21.849$; Sig. $F=0.000 ; R=0.388 ; R^{2}=0.151 ;$ Adjusted $R^{2}=0.144$
Predictors of knowledge transfer

Table VII. Results of simple linear regression for shared vision on knowledge transfer

\begin{tabular}{lcccc}
\hline & & \multicolumn{3}{c}{ Bootstrapping } \\
& & \multicolumn{3}{c}{ BC percentile 95\% CI } \\
& Point estimate $(\beta)$ & SE & & Lower \\
\hline As perceived by expatriates & & & & \\
$\quad$ Cultural intelligence (CQ) & 0.392 & 0.113 & 0.205 & 0.659 \\
$\begin{array}{c}\text { Feedback-seeking behavior (FSB) } \\
\text { As perceived by HCNs }\end{array}$ & 0.447 & 0.123 & 0.242 & 0.729 \\
$\quad$ Cultural intelligence (CQ) & 0.326 & 0.118 & 0.121 & 0.594 \\
Feedback-seeking behavior (FSB) & 0.217 & 0.089 & 0.079 & 0.438
\end{tabular}

Notes: $\mathrm{BC}$, bootstrap confidence; $\mathrm{CI}$, Confidence interval. Indirect effect is significant if 0 value falls outside the lower bound and upper bound of $\mathrm{BC}$ Percentile $95 \% \mathrm{CI}$
Table VIII.

Results of process method for mediation analysis 
EJMBE

29,2

\section{0}

Table IX.

The overall results of hypotheses
Hypothesis

Result

H1a: cultural intelligence influences knowledge transfer involving expatriates and HCNs as Not supported perceived by expatriates

H1b: cultural intelligence influences knowledge transfer involving expatriates and HCNs as Not supported perceived by $\mathrm{HCNs}$

H2a: feedback-seeking behavior influences knowledge transfer involving expatriates and Not supported HCNs as perceived by expatriates

$H 2 b$ : feedback-seeking behavior influences knowledge transfer involving expatriates and Not supported $\mathrm{HCNs}$ as perceived by HCNs

$H 3 a$ : shared vision influences knowledge transfer involving expatriates and HCNs as perceived by expatriates

$H 3 b$ : shared vision influences knowledge transfer involving expatriates and HCNs as Supported perceived by HCNs

H4a: shared vision mediates the relationship between cultural intelligence and knowledge Supported transfer involving expatriates and HCNs as perceived by expatriates

$H 4 b$ : shared vision mediates the relationship between cultural intelligence and knowledge Supported transfer involving expatriates and HCNs as perceived by HCNs

$H 4 c$ : shared vision mediates the relationship between feedback-seeking behavior and Supported knowledge transfer involving expatriates and HCNs as perceived by HCNs

H4d: shared vision mediates the relationship between feedback-seeking behavior and Supported knowledge transfer involving expatriates and $\mathrm{HCNs}$ as perceived by $\mathrm{HCNs}$

concurs with the powerful statement by Hitt et al. (2010) that in any organizational development, employees are supposed to act on the vision that has been informed by their managers and created by their leaders.

\section{Conclusion and implications}

Vision that is being shared concludes the critical importance of inter-employee social interaction involving expatriates and HCNs. Individual qualities of cultural intelligence and feedback-seeking behavior increase shared vision, which then become determinants of knowledge transfer. Furthermore, positive cultural intelligence and feedback-seeking behavior that characterize both groups of employees allow bi-directional knowledge transfer involving expatriates and HCNs to take place. Additionally, the coexistence of expatriates and HCNs adds to the dynamism of knowledge transfer as an interactive process. This further highlights the value of workplace diversity, which according to Ismail and Arokiasamy (2008) workplace diversity leads to the improvement of organizational performance in Malaysia.

In the bi-directional perspective of expatriates and $\mathrm{HCNs}$, this research has theoretically supported the significant capacity of shared vision as an enhancer to knowledge transfer, making use of the two individual qualities as the predictors. This is further verified by considering the signaling theory, the social capital theory and the anxiety and uncertainty theory altogether, which were commonly found separately in past studies. The bi-directional analysis used in this study has yielded some empirical evidence of the two-way manner of knowledge transfer (i.e. as perceived by expatriates and HCNs), and this certainly adds to the dynamic nature of knowledge transfer based on Malaysian context.

This study suggests several practical implications for MNCs and other organizations. At the beginning of expatriate assignment, involvement in special team building solutions are suggested with the purpose to encourage positive relationships between knowledge partners and to establish shared vision. In relation to this, six step-procedures should be considered to strengthen mission statement (www.emeraldgrouppublishing.com/learning/ managementthinking/articles/pdf/hitt.pdf): identify the needs of the stakeholders; identify a direction of the unit/department; draft preliminary statement of vision; solicit inputs from 
team members and boss; do revision to the preliminary mission statement; incorporate the vision into the unit's plan. Some of the suggested human resource activities are: mentoring program, best practice meetings, job shadowing, and knowledge fair (showcases the best practices). This is to capitalize on the spirit of sharing together of what to be desired and attained in the organization.

The study is insightful to managers and leaders of MNCs and other organizations as shared vision among employees provides direction for action at unit or departmental level even at times it is challenging. An effective leader has three interrelated attributes: the ability to create a vision, the ability to communicate the vision to others, and the ability to motivate and inspire employees to work toward the vision. Shared vision is evident to be powerful in both directions of knowledge transfer involving expatriates and HCNs, therefore MNCs and other organizations should put a great emphasis on this fact regardless of the type of employees, as vision utters an engaging future of the organization. This also suggests that in any vision monitoring and re-assessment, expatriates and local employees should be consulted equally.

Local organizations should imply certain quota in their employment policy for expatriates considering Kuala Lumpur is crowned the most expat-friendly city in Asia in 2017 (Patrick, 2017) and ranked sixth-best city for expatriates, a year later (New Straits Times, 2018). Furthermore, in improving overall organizational performance, this study suggests local organizations to consider bi-directional knowledge transfer involving expatriates as one of the criteria in HCNs' annual key performance indicator (KPI). This will create a more satisfactory working climate, and certainly attract more expatriates to work in the country.

Realizing the limitations of this study, future research issuggested as follows: the present framework is limited to internal resources of cultural intelligence, feedback-seeking behavior and shared vision. Other internal resources of firm's absorptive capacity such as shared culture, shared values, and strength of network between parent company and subsidiary in the country should be considered; comparison between the various merits of prior contact of expatriates with HCNs as compared to cross-cultural training of expatriates in knowledge transfer; the specific knowledge gained by expatriate vs HCNs through knowledge transfer using a longitudinal study approach; knowledge transfer using the same framework focusing on other types of pairing such as senior-junior or manageremployee dyads; and it is crucial for future research to include gender issues as expatriation is becoming one of non-traditional career options for women (Hansen, 2016), as well as men and women professionals have different individual and social capital qualities that may affect knowledge transfer differently.

\section{References}

Ado, A., Su, Z. and Wanjiru, R. (2016), "Learning and knowledge transfer in Africa-China JVs: interplay between informalities, culture, and social capital", Journal of International Management, Vol. 23 No. 2, pp. 166-179.

Ang, S. and Van Dyne, L. (2015), "Conceptualization of cultural intelligence: definition, distinctiveness, and nomological network", Handbook of Cultural Intelligence, Routledge, pp. 21-33.

Argote, L. (2012), Organizational Learning: Creating, Retaining and Transferring Knowledge, Springer Science and Business Media, Berlin.

Ashford, S.J. (1986), "Feedback-seeking in individual adaptation: a resource perspective", Academy of Management Journal, Vol. 29 No. 3, pp. 465-487.

Ashford, S.J., Blatt, R. and Walle, D.V. (2003), "Reflections on the looking glass: a review of research on feedback-seeking behavior in organizations", Journal of Management, Vol. 29 No. 6, pp. 773-799. 
EJMBE

29,2

Baron, R.M. and Kenny, D.A. (1986), "The moderator-mediator variable distinction in social psychological research: conceptual, strategic, and statistical considerations", Journal of Personality and Social Psychology, Vol. 51 No. 6, pp. 1173-1182.

Bonache, J. and Zárraga-Oberty, C. (2008), "Determinants of the success of international assignees as knowledge transferers: a theoretical framework", The International Journal of Human Resource Management, Vol. 19 No. 1, pp. 1-18.

Bresman, H., Birkinshaw, J. and Nobel, R. (1999), "Knowledge transfer in international acquisitions", Journal of International Business Studies, Vol. 30 No. 3, pp. 439-462.

Caligiuri, P.M. and Cascio, W.F. (1998), "Can we send her there? Maximizing the success of western women on global assignments", Journal of World Business, Vol. 33 No. 4, pp. 394-416.

Caniëls, M.C. (2019), "Proactivity and supervisor support in creative process engagement", European Management Journal, Vol. 37 No. 2, pp. 188-197.

Cassiman, B. and Veugelers, R. (2006), "In search of complementarity in innovation strategy: internal R\&D and external knowledge acquisition”, Management Science, Vol. 52 No. 1, pp. 68-82.

Chang, Y.Y., Gong, Y. and Peng, M.W. (2012), "Expatriate knowledge transfer, subsidiary absorptive capacity, and subsidiary performance", Academy of Management Journal, Vol. 55 No. 4, pp. 927-948.

Cohen, W. and Levinthal, D. (1989), "Innovation and learning: the two faces of R\&D”, Economic Journal, Vol. 99 No. 397, pp. 569-596.

Comeig, I., Mas-Tur, A. and Viglia, G. (2018), "Introduction to the special issue on innovation, knowledge absorption, judgement and decision-making processes", European Journal of Management and Business Economics, Vol. 27 No. 2, pp. 126-128.

Connelly, B.L., Certo, S.T., Ireland, R.D. and Reutzel, C.R. (2011), "Signaling theory: a review and assessment”, Journal of Management, Vol. 37 No. 1, pp. 39-67, doi: 10.1177/ 0149206310388419.

Crommelinck, M. and Anseel, F. (2013), "Understanding and encouraging feedback-seeking behavior: a literature review”, Medical Education, Vol. 47 No. 3, pp. 232-241.

Crowne, K.A. (2009), "The relationships among social intelligence, emotional intelligence and cultural intelligence", Organization Management Journal, Vol. 6 No. 3, pp. 148-163.

Deng, E. (2012), "Multinationals choose Greater Kuala Lumpur and Klang Valley as Asia base", available at: www.scmp.com/article/1046182/multinationals-choose-greater-kuala-lumpur-andklang-valley-asia-base (accessed January 2, 2019).

Department of Statistics Malaysia (2018), "Kuala Lumpur Population 2019", available at: http:// worldpopulationreview.com/world-cities/kuala-lumpur-population/ (accessed January 2, 2019).

De Stobbeleir, K.E., Ashford, S.J. and Buyens, D. (2011), "Self-regulation of creativity at work: the role of feedback-seeking behavior in creative performance", Academy of Management Journal, Vol. 54 No. 4, pp. 811-831.

Dhanaraj, C., Lyles, M.A., Steensma, H.K. and Tihanyi, L. (2004), "Managing tacit and explicit knowledge transfer in IJVs: the role of relational embeddedness and the impact on performance", Journal of International Business Studies, Vol. 35 No. 5, pp. 428-442.

Expósito-Langa, M., Molina-Morales, F.X. and Tomás-Miquel, J.V. (2010), "How shared vision moderates the effects of absorptive capacity and networking on clustered firms' innovation", Scandinavian Journal of Management, Vol. 31 No. 3, pp. 293-302.

Feitosa, J., Kreutzer, C., Kramperth, A.S., Kramer, W. and Salas, E. (2014), "Expatriate adjustment: considerations for selection and training", Journal of Global Mobility, Vol. 2 No. 2 , pp. 134-159.

Gudykunst, W.B. (1998), "Applying AnxietylUncertainty Management (AUM) Theory to intercultural adjustment training”, International Journal of Intercultural Relations, Vol. 22 No. 2, pp. 227-250.

Gutiérrez, L.J., Lloréns-Montes, F.J. and Bustinza Sánchez, O.F. (2009), "Six sigma: from a goal-theoretic perspective to shared-vision development", International Journal of Operations \& Production Managemen, Vol. 29 No. 2, pp. 151-169. 
Hansen, R.S. (2016), "The pros and cons of non-traditional careers: working in jobs that defy gender stereotypes”, Quintessential Careers, available at: www.livecareer.com/quintessential/pros-consnon-traditional-careers (accessed June 16, 2017).

Hayes, A.F. (2009), "Beyond Baron and Kenny: statistical mediation analysis in the new millennium", Communication Monographs, Vol. 76 No. 4, pp. 408-420.

Hayes, A.F. (2013), Introduction to Mediation, Moderation, and Conditional Process Analysis: A Regression-Based Approach, Guilford Press, New York, NY.

Hitt, M.A., Haynes, K.T. and Serpa, R. (2010), "Strategic leadership for the 21st century", Business Horizons, Vol. 53, pp. 437-444.

Hsu, Y.S. (2012), "Knowledge transfer between expatriates and host country nationals: a social capital perspective (Theses and dissertations, Paper 33)", University of Wisconsin Milwaukee UWM Digital Commons, Milwaukee, MI, available at: http://dx.doi.org/10.1037/e518332013-315

Inkpen, A.C. and Tsang, E.W. (2005), "Social capital, networks, and knowledge transfer”, Academy of Management Review, Vol. 30 No. 1, pp. 146-165.

Ismail, M. (2015), “Conceptualizing knowledge transfer between expatriates and host country nationals: the mediating effect of social capital”, Cogent Business \& Management, Vol. 2 No. 1, pp. 1-16.

Ismail, M. and Arokiasamy, L. (2008), "Workforce diversity: a human resource development perspective towards organizational performance”, European Journal of Social Sciences, Vol. 6 No. 2, pp. 244-251.

Ismail, M., Hamzah, S.R.A. and Bebenroth, R. (2018), "Differentiating knowledge transfer and technology transfer: what should an organizational manager need to know?”, European Journal of Training and Development, Vol. 42 No. 9, pp. 611-628.

Ismail, M., Zulkifly, N.A. and Hamzah, S.R. (2019), "The power of shared vision: bidirectional knowledge transfer between expatriates and host country nationals", International Journal of Business and Society, Vol. 20 No. 2, pp. 501-520.

Ismail, M., Sobri, S.S., Zulkifly, N.A., Hamzah, S.R. and Yamato, E. (2016), "Knowledge transfer between expatriates and host country nationals: contribution of individual and social capital factors", Organizations and Markets in Emerging Economies, Vol. 7 No. 2, pp. 65-87.

Jaeger, R.G. and Halliday, T.R. (1998), “On confirmatory versus exploratory research”, Herpetologica, Vol. 54 No. 2, pp. S64-S66.

Jawahar, I.M. and Schreurs, B. (2018), "Supervisor incivility and how it affects subordinates' performance: a matter of trust", Personnel Review, Vol. 47 No. 3, pp. 709-726.

Kashy, D.A. and Kenny, D.A. (2000), "The analysis of data from dyads and groups”, in Reis, H.T. and Judd, C.M. (Eds), Handbook of Research Methods in Social and Personality Psychology, Cambridge University Press, New York, NY, pp. 451-477.

Kodwani, A.D. (2012), "Beyond emotional intelligence (EQ): the role of cultural intelligence (CQ) on cross-border assignments", World Review of Business Research, Vol. 2 No. 4, pp. 86-102.

Krasman, J. (2010), “The feedback-seeking personality: big five and feedback-seeking behavior", Journal of Leadership and Organizational Studies, Vol. 17 No. 1, pp. 18-32.

Kumar, N. (2013), "Managing reverse knowledge flow in multinational corporations", Journal of Knowledge Management, Vol. 17 No. 5, pp. 695-708.

Lazuras, L., Barkoukis, V., Ourda, D. and Tsorbatzoudis, H. (2013), “A process model of cyberbullying in adolescence”, Computers in Human Behavior, Vol. 29 No. 3, pp. 881-887.

Li, L. (2005), "The effects of trust and shared vision on inward knowledge transfer in subsidiaries' intra-and inter-organizational relationships", International Business Review, Vol. 14 No. 1, pp. 77-95.

Lin, N. (1999), "Building a network theory of social capital", Connections, Vol. 22 No. 1, pp. 28-51.

Lin, N. (2017), "Building a network theory of social capital", Social Capital, Routledge, pp. 3-28.

Predictors of knowledge transfer 
EJMBE

29,2

Manzi, C., Coen, S., Regalia, C., Yévenes, A.M., Giuliani, C. and Vignoles, V.L. (2018), "Being in the Social: a cross-cultural and cross-generational study on identity processes related to Facebook use", Computers in Human Behavior, Vol. 80, March, pp. 81-87.

Minbaeva, D.B. and Michailova, S. (2004), "Knowledge transfer and expatriation in multinational corporations: the role of disseminative capacity”, Employee Relations, Vol. 26 No. 6, pp. 663-679.

Mohd Tahir, A.H. and Ismail, M. (2007), "Cross-cultural challenges and adjustments of expatriates: a case study in Malaysia", Alternatives: Turkish Journal of International Relations, Vol. 6 Nos $3 \&$ 4, pp. 72-99.

Molina, Y., Martínez-Gutiérrez, J., Püschel, K. and Thompson, B. (2013), "Plans to obtain a mammogram among Chilean women: the roles of recommendations and self-efficacy", Health education research, Vol. 28 No. 5, pp. 784-792.

Nahapiet, J. and Ghoshal, S. (1998), "Social capital, intellectual capital, and the organizational advantage”, Academy of Management Review, Vol. 23 No. 2, pp. 242-266.

NEAC (2010), New Economic Model for Malaysia - Part 1, Percetakan Nasional Malaysia Berhad, Kuala Lumpur, National Economic Advisory Council, available at: www.neac.gov.my (accessed April 7, 2011).

Nery-Kjerfve, T. and McLean, G.N. (2012), "Repatriation of expatriate employees, knowledge transfer, and organizational learning: what do we know?", European Journal of Training and Development, Vol. 36 No. 6, pp. 614-629.

New Straits Times (2018), "KL sixth best city in the world for expats: survey", November 20, p. 1, available at: www.nst.com.my/news/nation/2018/11/433079/kl-sixth-best-city-world-expatssurvey (accessed January 1, 2019).

Oddou, G., Osland, J.S. and Blakeney, R.N. (2009), "Repatriating knowledge: variables influencing the 'transfer' process", Journal of International Business Studies, Vol. 40 No. 2, pp. 181-199.

Patrick, H. (2017), "Kuala Lumpur crowned the most expat-friendly city in Asia", available at: https:// asiancorrespondent.com/2017/11/kuala-lumpur-crowned-expat-friendly-city-asia/ (accessed January 7, 2019).

Peraza, N., Smit, T., Garey, L., Manning, K., Buckner, J.D. and Zvolensky, M.J. (2019), "Distress tolerance and cessation-related cannabis processes: the role of cannabis use coping motives", Addictive Behaviors, Vol. 90, March, pp. 164-170.

Pinto, R. (2014), "Expats in Malaysia: what you should know", available at: www.expatgocom/my/20 14/02/24/expats-in-malaysia-what-you-should-know (accessed January 7, 2019).

Preacher, K.J. and Hayes, A.F. (2004), "SPSS and SAS procedures for estimating indirect effects in simple mediation models", Behavior Research Methods, Vol. 36 No. 4, pp. 717-731.

Preacher, K.J. and Hayes, A.F. (2008), "Asymptotic and resampling strategies for assessing and comparing indirect effects in multiple mediator models", Behavior Research Methods, Vol. 40 No. 3, pp. 879-891.

Robert, L.M., Dutton, J.E., Spreitzer, G.M., Heaphy, E.D. and Quinn, R.E. (2005), “Composing the reflected best-self portrait: building pathways for becoming extraordinary in work organizations", Academy of Management Review, Vol. 30 No. 4, pp. 712-736.

Roueche, P.E., Baker, G.A. III and Rose, R.R. (2014), Shared Vision: Transformational Leadership in American Community Colleges, Rowman \& Littlefield, Lanham.

Senge, P.M. (2006), The Fifth Discipline: The Art and Practice of the Learning Organization, Broadway Business.

Smale, A. and Suutari, V. (2011), "Expatriate perspectives on knowledge transfers into Central and Eastern Europe", in Mariano, S., Mohamed, M. and Mohiuddin, Q. (Eds), The Role of Expatriates in MNCs Knowledge Mobilization, Emerald Group Publishing Limited, Bingley, pp. 63-90.

Song, J., Almeida, P. and Wu, G. (2003), "Learning-by-hiring: when is mobility more likely to facilitate interfirm knowledge transfer?", Management Science, Vol. 49 No. 4, pp. 351-365. 
Spence, M. (2002), "Signaling in retrospect and the informational structure of markets", American Economic Review, Vol. 92 No. 3, pp. 434-459.

Stebbins, R.A. (2001), Exploratory Research in The Social Sciences, Vol. 48, Sage, London.

Tan, B.S. and Yap, E.H. (2015), "Sustainable growth of the commercial aviation industry in Malaysia using a system dynamics approach", Journal of Engineering, Science and Technology, Vol. 10 No. 9, pp. 1150-1161.

Tsai, W. and Ghoshal, S. (1998), "Social capital and value creation: the role of intrafirm networks", Academy of Management Journal, Vol. 41 No. 4, pp. 464-478.

Tsang, E.W. (2001), "Managerial learning in foreign-invested enterprises of China”, MIR: Management International Review, Vol. 41 No. 1, pp. 29-51.

Upadhyayula, R.S. and Kumar, R. (2004), "Social capital as an antecedent of absorptive capacity of firms", DRUID Conference 2004: Industrial Dynamics, Innovation and Development, Elsinore, pp. 1-30.

Uzzi, B. and Lancaster, R. (2003), "Relational embeddedness and learning: the case of bank loan managers and their clients", Management Science, Vol. 49 No. 4, pp. 383-399.

Van Wijk, R., Jansen, J.J. and Lyles, M.A. (2008), "Inter-and intra-organizational knowledge transfer: a meta-analytic review and assessment of its antecedents and consequences", Journal of Management Studies, Vol. 45 No. 4, pp. 830-853.

VandeWalle, D. (2004), "A goal orientation model of feedback-seeking behavior", Human Resource Management Review, Vol. 13 No. 4, pp. 581-604.

Wang, C.L. and Rafiq, M. (2009), "Organizational diversity and shared vision: resolving the paradox of exploratory and exploitative learning”, European Journal of Innovation Management, Vol. 12 No. 1, pp. 86-101.

Webb, A. (1996), “The expatriate experience: implications for career success”, Career Development International, Vol. 1 No. 5, pp. 38-44.

Yli-Renko, H., Autio, E. and Sapienza, H.J. (2001), "Social capital, knowledge acquisition, and knowledge exploitation in young technology-based firms”, Strategic Management Journal, Vol. 22 Nos 6-7, pp. 587-613.

Yoshitake, M. (2002), "Anxiety/uncertainty management (AUM) theory: a critical examination of an intercultural communication theory", Intercultural Communication Studies, Vol. 11 No. 2, pp. 177-193.

\section{Further reading}

Ringle, C.M., Sarstedt, M. and Straub, D.W. (2012), "Editor's comments: a critical look at the use of PLS-SEM", MIS Quarterly, Vol. 36 No. 1, p. iii.

Siddiqui, K. (2013), "Heuristics for sample size determination in multivariate statistical techniques", World Applied Sciences Journal, Vol. 27 No. 2, pp. 285-287, doi: 10.5829/idosi.wasj.2013.27.02.889.

\section{Corresponding author}

Nurul Afiqah Zulkifly can be contacted at: afiqahzulkifly@yahoo.com

For instructions on how to order reprints of this article, please visit our website:

www.emeraldgrouppublishing.com/licensing/reprints.htm

Or contact us for further details: permissions@emeraldinsight.com 